\title{
Not meant to last: mobility and disposable pottery
}

\author{
Kevin Gibbs \\ Department of Archaeology, University of Aberdeen, Aberdeen, Scotland, UK \\ kevin.gibbs@abdn.ac.uk
}

\begin{abstract}
Discussions of the emergence of pottery have often focused on the development of durable vessels among sedentary societies. However, there is increasing appreciation of the fact that early pottery was sometimes used by mobile groups, such as Late Pleistocene hunter-gatherers in East Asia and perhaps Late Neolithic pastoral nomads in the Near East. Pottery that was not intended to have a long use-life, i.e. disposable pottery, could have been used to resolve some of the conflicts between pottery production and a mobile way of life, including scheduling conflicts, length of production episodes, portability and scale of production.
\end{abstract}

IZVLEČEK - Diskusije o pojavu lončenine so bile pogosto usmerjene v študije o razvoju obstojnih posod med stalno naseljenimi družbami. Vendar pa se v zadnjem času vedno več pozornosti posveča tudi dejstvu, da so lončenino uporabljale tudi mobilne skupnosti, kot so pozno-paleolitski lovci in nabiralci v vzhodni Aziji ter morda tudi pozno-neolitski pastoralni nomadi na Bližnjem vzhodu. Lončenina, ki ni bila izdelana z namenom dolge uporabe, tj. lončenina za kratkotrajno uporabo, je morda služila reševanju neskladnosti med proizvodnjo lončenine na eni in mobilnim načinom življenja na drugi strani. Te neskladnosti so med drugim odpravljali z načrtovanjem dejavnosti, s krajšim časom proizvodnje, prenosnostjo in z obsegom proizvodnje.

KEY WORDS - pottery; disposable pottery; mobility; East Asia; Near East

\section{Introduction}

A number of recent publications indicate that the emergence of pottery remains an important topic in Old World archaeology (e.g., Barnett, Hoopes 1995; Gheorghiu 2009; Jordan, Zvelebil 2009a; Rice 1999; Yasuda 2002). Models from a range of theoretical perspectives have been proposed to explain why people began using fired clay vessels (Brown 1989; Rice 1999). A recurring theme implicit in some of these models is that pottery developed as a durable container that was intended to have a long use-life. But is it possible that early pots were not always fashioned with longevity in mind? Were pots sometimes used for a short period, perhaps to achieve a single, specific task, and then discarded? Accepting that the origins of pottery was likely complex and varied, this paper explores the potential roles of 'disposable' pottery in early pottery-using groups and speculates that disposable pottery may have particular advantages for mobile groups.

\section{Pottery origins and mobility}

Explanations for the adoption of pottery come from a variety of perspectives (Rice 1999). However, many recent discussions have stressed either the functional advantages of pottery or its potential role as a prestige object. Functionalist explanations typically consider pottery an adaptation for food preparation, and focus on its benefits as a watertight and vermin-proof storage container, or emphasise its role in new culinary contexts (Rice 1999.6-10). Such explanations suggest that the introduction of new foodstuffs or the benefits of cooking food in a more efficient way - through the direct application of heat 
- provided the stimulus for the adoption of pottery as a functionally superior container.

Explanations that consider the prestige value of pottery have built primarily on the work of Brian Hayden $(1995 ; 1998)$, who argues that early pottery played a role in ritual feasting displays, especially in the context of increasing resource intensification. Feasts allowed aggrandising individuals to impress or mobilise others and thereby influence socio-economic relationships. As a new and presumably difficult item to make, pottery would have had prestige value that could enhance the status of its owner. During feasts, pottery - and especially fine, decorated pottery - could be used to display or serve prestige foods, such as oils or alcohol. Hayden (2009) suggests that undecorated and seemingly utilitarian vessels can be explained from a prestige perspective if they were involved in the preparation of these foods.

These two kinds of explanation - functionalist and prestige - differ in significant ways, yet in both there is an emphasis on well-made pottery that was presumably intended to be durable. For functionalist explanations, there is an expectation that early pottery should be sufficiently well-made in order to fulfil its functional roles as a cooking or storage container. While there may have been early phases of experimentation characterised by cruder vessels (e.g., Brown 1989), the development of pottery should be towards well-made, functional vessels, as potters become more familiar with the craft. Explanations that consider pottery to be a prestige technology typically focus on fine, decorated wares that would have been the result of a significant investment of time and resources in order to produce an object that would convey the status of its owner, especially during feasting events. A less well-made pot would not convey this message as convincingly. If early pots were made to cook prestige foods, rather than serve them, or stand as prestige objects in their own right (Hayden 2009), they should be well made in order to operate in this capacity. Indeed, they may have needed to be more efficient cooking vessels than those implied in functionalist models if prestige foods were more difficult and demanding to prepare or less familiar to the people preparing them.

Both kinds of models have also tended to focus on pottery production by sedentary groups. Functionalist models have looked at the new foods made available by agriculture, particularly in the Near East and parts of Europe. Alternatively, they consider the relationship between pottery and the intensive exploi- tation of specific resources by relatively sedentary complex hunter-gatherers, such as grasses, nuts, fish or shellfish. Likewise, prestige models have tended to focus on pottery use and feasting among complex hunter-gatherers exhibiting emerging social inequalities and limited residential mobility (Hayden 1995. 258).

Indeed, there are a number of reasons why pottery may seem to be an unattractive container option for mobile groups:

(1) Pottery is easiest to make during warm and dry times of the year. While mobile groups may be able to move to areas with suitable raw material sources for pottery production, to do so at the appropriate time of year may be difficult, due to scheduling conflicts with other activities (Arnold 1985.120).

(2) Pottery production can require a significant investment of time, being protracted over several days or weeks. Specific raw materials may need to be procured and processed, including clay, temper, and fuel. Forming a vessel can require multiple production stages separated by lengthy periods of drying. Sufficient drying time is also crucial prior to firing, as otherwise the vessel may not survive the firing process. It may be difficult for mobile populations to remain in one place while these steps are being completed and, compared to the production of other container technologies, pottery is difficult to move prior to completion (Arnold 1985.119; Brown 1989).

3 In addition to being difficult to move during production, pottery is arguably difficult to transport after completion. Compared to some other containers that would have been available to early pottery users, such as basketry and skin bags, pots are heavy and more fragile. Some have argued that these properties would make them an unattractive container option for mobile groups (e.g., Driver, Massey 1957. 231; cf. Arnold 1985.110).

(4) There may be limited demand for containers in mobile groups with low population sizes. One of the main advantages of pottery over other container technologies is that time, materials (especially fuel), and effort are saved by producing multiple vessels at once (Brown 1989). Small groups that do not require many pots cannot take advantage of this economy of scale. Jelmer W. Eerkens (2008.310) suggests that in arid regions the limited availability of fuel would make small-batch firing particularly inefficient. 
Despite these limitations, there is clear evidence that mobile groups do sometimes use pottery. Arnold's (1985.Tab. 5.3) analysis of pottery making and sedentariness indicates that $25 \%$ of nomadic groups make pottery, as do $75 \%$ of partly sedentary groups. In some cases, mobile groups may not make pottery themselves, but will use pots acquired from sedentary communities (Beck 2009).

How can mobile groups resolve the conflicts associated with pottery production and a mobile lifestyle (see also Eerkens 2008; Simms et al. 1997)? One way of dealing with the limitations of heavy, breakable pottery, and resolving scheduling conflicts associated with pottery production is for a group to become more sedentary. It is possible that in some regions, pottery and sedentism developed in tandem. However, at many early pottery sites, there is little evidence for permanent settlement, and sedentism was seasonal at best (Rice 1999.24). The earliest experiments in pottery during the East Asian Late Pleistocene were by hunter-gatherers that were probably quite similar to the mobile groups of the preceding Palaeolithic in terms of social organisation and economy, and they likely maintained a high level of residential mobility (e.g., Habu 2004. 248; Kaner 2009.107; see below). Similarly, early Holocene pottery in North Africa was likely produced by relatively mobile hunter-gatherers (Close 1995.23). In later periods, mobile groups may have resolved production conflicts by acquiring pottery from sedentary populations (Beck 2009), but this was not an option for the earliest pottery users.

Another, less dramatic, way that mobile groups can accommodate pottery is through caching vessels. This resolves the issue of carrying around heavy, breakable vessels, although caching does not obviously alleviate problems associated with production scheduling conflicts. Eerkens (2008) demonstrates that mobile groups in the American western Great Basin cached pots. Caches in the region are sometimes found, especially in caves and rock shelters, and the uneven distribution of sherds across the landscape indicates that pottery was not carried into upland areas and was likely cached in the lowlands (Eerkens 2008.314).

A third option for resolving the conflict between pottery and mobility is to design vessels with mobility in mind. Philippe Crombé (2009.485) suggests that hunter-gatherers in Western Europe might have made pots with pointed rather than rounded bases because they are "easier to carry on the back, the hip or to transport in a canoe". Eerkens (2003. 734 ) indicates that in the western Great Basin, pots associated with residentially mobile groups were thinner and smaller than those of more sedentary groups, making them lighter to carry, in addition to being efficient cooking vessels in an area with limited fuel sources. Using fibre as temper can increase the porosity of a vessel and therefore reduce its weight, making it lighter to transport (Skibo et al. 1989), while perforations and appendages can serve as handles, making a pot easier to carry (Beck 2009. 331).

Another option that has rarely been discussed is to make vessels that are not intended to have a long use-life; in other words, to make disposable pottery. Simms et al. (1997) suggest that there may be an overall lower investment in pottery manufacture by more mobile groups, resulting in pots with shorter use-lives. They note a correlation in the eastern Great Basin between high residential mobility and thick-walled vessels made with little preparation of temper, which they take to be indicators of low investment in pottery manufacture. While they interpret a short use-life as a disadvantage that needs to be balanced against other factors, such as labour costs, material costs, and portability (Simms et al. 1997. 782), is it possible that in some contexts pottery with a short use-life was a calculated response to a mobile way of life? If pottery was intended to be disposable, a short use-life should not necessarily be considered a drawback.

\section{Disposable pottery}

Most discussions of pottery in archaeology have taken the position that pottery was typically produced with durability and longevity in mind. James M. Skibo and Michael B. Schiffer (1995.82), for example, state that:

"Unless potters build obsolescence into the design (as in car brakes or pantyhose), they generally want vessels to last as long as possible. This is especially true when pots are manufactured on a household, part-time basis for local use".

This is likely true in many cases of pottery production and perhaps in most cases of pottery production by sedentary populations (but see below). However, the statement should not be uncritically applied to all cases, and it is worth considering the potential significance of disposable pottery in certain contexts. 
Indeed, disposable pottery is not unknown from archaeological or ethnographic contexts, although, in fact, most examples derive from sedentary groups rather than mobile ones. For example, in the Kathmandu Valley, Judy Birmingham (1975.380) notes the use of disposable pots that are characterised by 'their careless workmanship and thin walls'. These are used in both religious and domestic contexts; the latter include tea and rakshi cups that are thrown away after use. Monica L. Smith (2008.225) suggests that deposits of string-cut bowls found between structures at the $3^{\text {rd }}$ century $\mathrm{BC}$ to $4^{\text {th }}$ century $\mathrm{AD}$ site at Sisupalgarh in eastern India may be comprised of single-use vessels. During the Middle Minoan III and Late Minoan IA periods on Crete, undecorated 'conical cups' were made rapidly and sometimes carelessly, perhaps for acts of token hospitality involving the offering of small amounts of food or drink to guests. These wheel-made vessels may have been used only once before being discarded (Knappett 2011.120; Rupp, Tsipopolou 1999). During the Uruk period in Mesopotamia (4th millennium BC), relatively crude, bevel-rim bowls were made in large numbers, perhaps to be used as bread moulds (Chazan, Lehner 1990; Millard 1988). These may have been produced cheaply in anticipation of demand and, if the demand decreased or failed to materialise, disposed of after a short time or even without ever being used (Goulder 2010.358).

While the above examples are concerned primarily with the discard of mass-produced pottery that was probably made by specialist potters, there has also been limited discussion in archaeology of smallerscale pottery production involving vessels with intended short use-lives. However, this discussion has tended to focus on social or ritual uses of pottery rather than its domestic or utilitarian ones. For example, Karen D. Vitelli (1999) implies that potters at the Neolithic site of Franchthi Cave in Greece may not have been overly concerned if their vessels crumbled or spalled shortly after manufacture, because it was the process of making pots that was important, rather than the resulting product. She suggests that shamans made pottery as a 'magical' transformative process, and as part of this process a pot that survived firing but then started to crumble or spall shortly after might have had 'great mystical potential' (Vitelli 1999.193). In a different scenario, Hayden (1995.261) suggests that fine, prestige vessels could be dramatically broken during feasts as displays of wealth, potentially not long after their manufacture. As an example, Anne B. Gebauer (1995. 108 ) suggests that in southern Scandinavia, deco- rated Funnel Beaker pottery was sometimes produced specifically to be smashed during rituals at megalithic tombs and causewayed camps in demonstrations of wealth and status. The symbolic impact of its destruction likely derived from the fact that it was a prestige rather than practical object (Hayden 1998).

Discussions of small-scale production of potentially disposable pots with more utilitarian or domestic roles are largely absent. The difficulty of identifying disposable, utilitarian pottery produced at the household level is likely part of the reason for this. In cases of mass production by specialist potters, disposability can potentially be identified by abundance and depositional context, as at Sisupalgarh (Smith 2008). Numerous, similar vessels found in a single deposit may be interpreted as disposable, especially if some appear to be intentionally broken. However, in the earliest stages of pottery manufacture, production did not typically result in great numbers of pots, and vessels were more likely to have been discarded in small numbers or individually. In this context, the identification of a pot as disposable is unlikely to be straightforward, and indeed, it may be inherently challenging. Pots that were not designed to last may preserve less well than ones made with durability and longevity in mind, so evidence may be scant. However, it is unlikely that true obsolescence would have been built into early disposable pottery, as this would require more effort than a pot that is intended to be thrown away is likely to receive. Therefore, disposable pots and ones that were fashioned with longevity in mind may both survive in archaeological deposits. Differentiating them is a challenge for the archaeologist.

It is perhaps best to think of a disposable pot as one to which the user was not attached, or was willing to discard, rather than one that was designed to fail or disintegrate after a set amount of time. Disposability, then, may be more a perception of the maker and/or user than a quality inherent in a particular pot. But as a point of departure for studies that aim to explore the potential role of disposable pots in the context of small-scale domestic production, it is useful to consider the kinds of vessel that people might have been willing to discard. In the context of early production, it is likely that little effort would have gone into producing a disposable pot and little effort would be made to preserve it. Many early disposable pots, then - at least those not made as prestige objects for destruction or deposition in ritual contexts (Hayden 1998.14) - could have been 
expediently produced, with little preparation of raw materials and little care taken in their forming and firing. This would generally result in a friable, uneven, low-fired and undecorated vessel. This gives a somewhat different picture of early pottery production than the ones implied by some functionalist or prestige models of pottery production. As noted above, these models suggest that early pottery should have been directed towards the development of wellmade vessels to fulfil functional roles or to serve as prestige objects.

It is worth noting here that not all 'coarse wares' should be considered expediently produced and certainly not all should be considered disposable. Many cooking pots and storage vessels that could be described as coarse were undoubtedly intended to have long use-lives and were carefully designed to fulfill their functional roles. Indeed, coarse and 'ugly' vessels can have specific qualities that make them functionally superior to their 'fine ware' counterparts (Skibo, Schiffer 1995.83). In broad categories of pottery types, expediently produced pots may exist as a separate category alongside other coarse wares and fine wares, although the boundaries between any such groupings are likely to be somewhat artificial and difficult to define.

While there has been little discussion of disposable pottery use by non-sedentary groups, and particularly disposable utilitarian pottery use, it may be interesting to speculate how disposable pottery may have helped to resolve some of the conflicts between pottery production and mobility, including scheduling conflicts, production time, portability and, to a certain extent, scale of production:

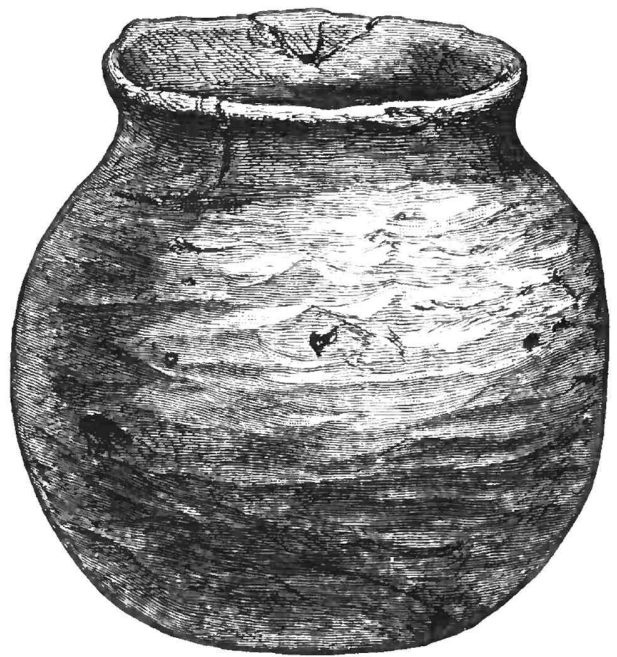

Fig. 1. Craggan from the Isle of Lewis (Mitchell 1880.Fig. 20).
(1) If pots are not intended to be durable, potters may not be overly concerned about waiting until the optimal time of year to produce them. Although it may be better to make pottery during the warm, dry summer months, especially if vessel durability is a primary goal, vessels can be produced at other times and in environments that are cold and humid. For example, in coastal Alaska, prehistoric groups made pottery despite living in a cold and wet climate that was seemingly unsuited to the task (Harry, Frink 2009). The kinds of low fired and 'ugly' vessels that can be produced during the cold, wet times of the year may be potential candidates for disposable pottery, although there is no specific indication that the Alaskan examples were meant to be disposable.

(2) Making this kind of pot may not involve a significant investment of time, allowing their producers to maintain a high degree of mobility. While some potters do invest a substantial amount of time in making a pot, others do not. For example, Arthur Mitchell (1880.26-8) describes $19^{\text {th }}$ century pottery production on the Isle of Lewis. Certain vessels (called craggans) were produced quickly, with little preparation of materials and using no special tools (Fig. 1). Despite the cool, humid environment of the Outer Hebrides, vessels were only dried for a day and they were fired in the household hearth, alleviating the necessity to construct any special or dedicated firing installation.

(3) The fact that pots may be relatively difficult to transport, being heavy and breakable, would not be a problem for mobile groups if they were not concerned about keeping them during residential moves. Pots could simply be discarded prior to relocation. Edward L. Ochsenschlager (1974) observes that Hadij Bedouin of southern Iraq would fashion vessels and other objects from unfired clay. While these could potentially survive for years and were sometimes mended, they would be left behind when the campsite was moved (Ochsenschlager 1974. 164). Mbuti foragers in the Democratic Republic of Congo acquire pots from settled groups when they are camping in the latter's villages (Turnbull 1965. 36), but upon returning to the forest they leave most of these behind (Turnbull 1965.Fig. 10). Lowfired vessels could have been treated in similar ways by early pottery-using groups.

(4) The economy of scale proposed by James A. Brown (1989) suggests that a primary benefit of pottery is that making pots in batches reduces the 
amount of time and resources required per individual vessel, making them a cheap alternative to competing container technologies such as baskets or stone bowls. However, an expediently-produced, disposable pot may be considered 'cheap' even if made singly, since there is minimal initial investment of resources and little room for optimising the production process. Vessels like Mitchell's craggans did not require lengthy periods of drying between stages of manufacture and were fired in hearths that are also being used for other purposes. The production of this kind of vessel will benefit less from Brown's (1989) economy of scale than the production of vessels that were the result of higher investments of time and energy, which could be optimised through bulk production.

\section{Case studies}

Identifying potential case studies of the small-scale production of disposable early pottery by mobile groups is hampered by 1) the inherent problems of identifying disposable pottery (discussed above) and, in some cases, 2) difficulties with identifying the sites of mobile groups. The sites produced by mobile groups may be difficult to locate if they are small or ephemeral. Furthermore, because the presence of pottery at a site is sometimes interpreted as an indicator of sedentariness, even if the sites of mobile pottery using groups are located, they might not be identified as such.

However, as a point of departure for further examinations of disposable early pottery use by mobile groups, I propose two (speculative) cases where a reinterpretation of the evidence could lead to fruitful discussions of disposable pottery.

\section{East Asia}

Despite a long tradition of viewing pottery as part of a 'Neolithic package' that also included agriculture and sedentism, it is now clear that the world's first pottery was not produced by sedentary farmers, but rather by Late Pleistocene hunter-gatherers in East Asia (Jordan, Zvelebil 2009b). Early dates for pottery come from southern China at around 18300 to 15430 calBP (Boaretto et al. 2009) and Japan and the Russian Far East around 16230 calBP (Keally et al. 2003; Kuzmin 2006). Much of the earliest pottery in these regions is undecorated and rather coarse. For example, Lu (2010.18) describes early pottery from Zengpiyan as low-fired (probably below $250^{\circ} \mathrm{C}$ ) and often plain, and suggests that the marks and impressions preserved on vessel surfaces are not decoration but, rather, traces of the manufacturing process that were not subsequently removed (Fig. 2). The earliest phase of pottery production in Japan is also characterised by undecorated wares (Keally et al. 2003).

This kind of pottery is often attributed to an early experimental stage of production when potters had yet to realise the full potential of the craft (Brown 1989). However, it is not inconsistent with the kind of expediently produced pottery that I suggest was, in some cases, made to be disposable. It should be noted that not all early pottery from East Asia is undecorated. For example, at Xianrendong in southern China, pots were sometimes decorated with $\mathrm{U}$ or V-shaped impressions along the rim, often with a lower band of circular impressions running around the vessel (Zhang 2002). Pottery from the region also shows some attention to paste preparation, with ground quartzite often being added as temper, although this can be rather coarse and poorly sorted. The co-occurrence of potentially expedient vessels and more carefully made decorated pots suggests that there was not always a straightforward experimental stage of pottery production that progressed directly into more developed traditions. Rather, it seems that potentially expedient pots were sometimes made alongside ones that were more carefully manufactured, suggesting that potters intentionally chose to make expedient pots and were not simply limited by their technological know-how.

In some parts of East Asia, it is possible that the emergence of pottery coincided with a shift to a more sedentary way of life. In southern Kyushu, seasonally sedentary settlements develop around the same time as early pottery during the Incipient Jōmon period, and by the subsequent Initial Jōmon period some settlements were occupied throughout the year (Pearson 2006). However, the overall trajectory towards increasing sedentism remains some-

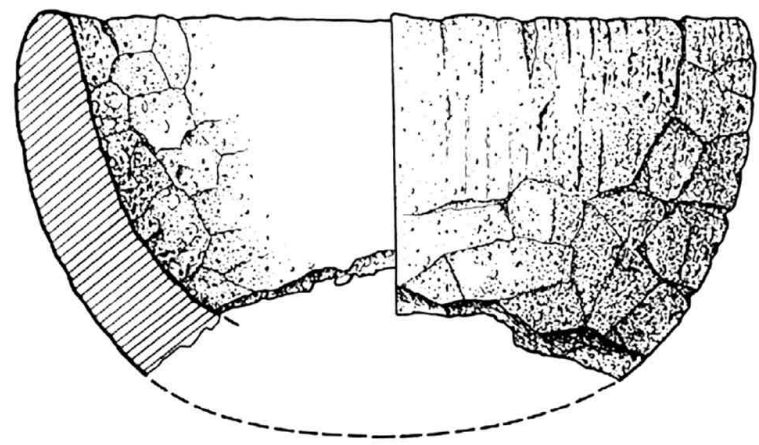

Fig. 2. Early pottery from Zengpiyan, southern China (after Lu 2010.Fig. 2). 
what unclear for the broader region and was likely rather complex. It is probable that in some areas the first pottery users were quite mobile (e.g., $\mathrm{Habu}$ 2004.248 ), with greater sedentism developing only at a later stage of the Pleistocene-Holocene transition. In central Honshu, Simon Kaner (2009.107) suggests that the earliest undecorated pottery was made by people who were still very mobile. It was not until the next stage of pottery production, when decorated vessels became more common, that people began to range less widely (Kaner 2009.109).

\section{Near East}

Early pottery use by mobile populations is not necessarily restricted to hunter-gatherers. Nomadic pastoralism represents another mobility strategy that could incorporate disposable pottery. In the southern Levant, the emergence of pottery marks the start of the Late (or Pottery) Neolithic period (c. 6500$5200 \mathrm{BC}$ ). Sheep and goats form a dominant part of the faunal assemblages from this time, suggesting that nomadic pastoralism may have been an important part of the economy. Ilse Köhler-Rollefson (1992) has argued that nomadic pastoralism developed in eastern Jordan as a means of alleviating the environmental pressures caused by animals grazing around large habitation sites, such as 'Ain Ghazal. Herders would remove their flocks from the site at certain times of year to graze in the steppe to the east. This resulted in a 'disarticulated' society comprised of both settled farmers and mobile herders who would leave the sites for extended periods of time (Rollefson, Köhler-Rollefson 1993.39). While the specifics of this model have been debated (e.g., Betts 2008), it does seem that farming and herding were two parts of the Late Neolithic economy, and the occasional interaction between farmers and herders could possibly account for some of the pottery recovered from Late Neolithic sites.

At the Late Neolithic site of al-Basatîn in northern Jordan, excavations have produced some evidence for a small but relatively settled group, including sickles and ground stone objects for harvesting and processing grain, and the remains of pigs, which are not usually associated with nomadic communities (Kadowaki et al. 2008). However, architecture at the site is somewhat ephemeral, perhaps consisting of stone platforms covered by tent-like structures (Kadowaki et al. 2008), and sheep and goat bones dominate the assemblage. Although it is not certain, this could be interpreted as a more mobile component within the settlement or, perhaps, the development of the site included multiple stages, some of which included more temporary occupations (see Bernbeck 2008). Pottery at the site includes some relatively fine vessels, including small numbers of thin-walled and highly burnished pottery, but it also includes some coarse (even 'ugly') and probably hastily made vessels that are so friable they cannot be washed without risking disintegration (Fig. 3). Examining the fabric of this material shows that pots were sometimes made with little preparation of raw materials; they had no temper added and were made with unlevigated clay. A possible interpretation is that these were expediently produced vessels used by a more temporary and mobile component of the group. When this component relocated with their flocks, perhaps to the highlands to the east, they could have left these disposable pots behind. The difficulty of identifying ephemeral pastoral campsites makes it difficult to establish whether Late Neolithic nomadic groups also made pottery when away from larger settlements, although it is worth noting that Late Neolithic sites in the eastern desert rarely contain pottery (Betts 1998). This interpretation is admittedly speculative, but it is a direction that may warrant further consideration.

\section{Beyond mobility}

While this paper emphasises the role of disposable pottery in resolving some of the conflicts between pottery production and mobility, the idea of disposability may contribute to addressing some other issues related to early pottery production. For example, Vitelli (1999) has questioned why potters would have experimented with adding calcite or shell temper to pottery. These additions can provide some functional benefits to a vessel if added in the right combination, but they can also cause a pot to mar or crumble entirely, making it difficult to "explain why

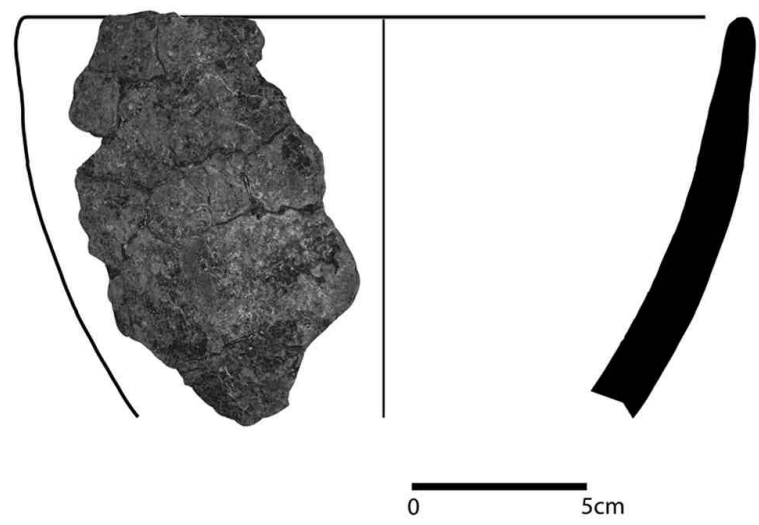

Fig. 3. Late Neolithic rim sherd from al-Basatîn, northern Jordan. 
it ever occurred to anyone to try that combination in the first place, and to persist until they came up with the right proportions" (Vitelli 1999.193). As noted above, her answer is that a pot that marred or crumbled some time after manufacture may have been interpreted in terms of the mystical properties of the shaman-potter. Another possibility is that pots were only intended to be used for a short time, perhaps for a specific domestic activity. If they fell apart when this activity was completed, it may not have been a particular concern for the potter and/or user. In this case, calcite or shell temper may have been no more risky than any other additive. The discovery that certain combinations of clay, temper and firing conditions resulted in pots that did not crumble could have been an unintended consequence resulting from the preservation of some vessels and not others.

Prudence M. Rice (1999.21-3) has noted that early pottery is frequently found in riverine or coastal environments. One explanation for this pattern is that people were drawn to the rich food resources available in such areas. Ultimately, this resource abundance could tether groups to specific locations, resulting in increased sedentism, which could facilitate pottery production. An alternative explanation is that mobile pottery-producing groups were attracted to riverine environments because these could provide relatively predictable sources of the raw materials required to make pottery - clay, water, and fuel. If pots were repeatedly being produced and discarded, then a predictable source of raw materials would be beneficial when a group moved to a new location and wanted to quickly form a new pot. Of course, these two explanations are not mutually exclusive, and it is highly likely that groups were drawn to riverine and coastal locations for a broad range of products (Jordan, Zvelebil 2009b.59). It is worth pointing out, however, that the earliest pottery production in East Asia predates the onset of climatic amelioration events that presumably led to increases in riverine food resources (Taniguchi 2006). It seems that there was not a straightforward progression from an increase in riverine resources to sedentism and the production of pottery.

The idea of disposability may also help explain why the 'experimental' stage of pottery production seems to last so long. Brown (1989) suggests that the widespread adoption of pottery should be preceded by an experimental stage characterised by expedient production techniques, and indeed, in some areas, pottery that could be described as expedient existed for centuries or millennia before the emergence of finer wares. But Oyuela-Caycedo (1995.134) notes that "pottery could have been invented in such a short period of time that its development would not even be perceived in the archaeological record". The time lag may be explained if crude, expedient pottery was not, in fact, experimental, but rather had advantages over finer and seemingly more sophisticated wares. While such 'ugly' pottery may have some functional advantages for cooking (Skibo, Schiffer 1995), the low investment of time and material resources required for disposable pots may have been another advantage. Disposable pots should not require great investments of time or resources to make or maintain, and do not have to be accommodated in residential moves.

Building on this, it is worth pointing out that many early pottery assemblages are quite small. For example, for the earliest phase of the Incipient Jōmon of Japan the average number of recovered sherds per site is only 28 (Keally et al. 2003.9). This low number may suggest that very early pottery was a barely sustainable technology and one might question how it managed to survive and develop into larger scales of production. However, if many early vessels did not preserve because they were not designed or intended to be durable, the actual number of pots made by early potters could have been higher (but see above). These higher numbers could indicate a more sustainable level of early production, which helps to explain why pottery eventually became such a widespread phenomenon.

\section{Conclusion}

It is becoming increasingly clear that the factors contributing to the emergence of pottery varied from region to region, depending on specific ecological, economic and social conditions (Hoopes, Barnett 1995). The reasons for the emergence of pottery in East Asia were likely rather different from those that led to early pottery in North Africa, the Near East, or anywhere else. Therefore, any broad statements about the importance of disposable pottery may not be relevant in all areas. However, in general terms, I suggest that there may be some particular advantages to disposable pottery for mobile groups. Considering these advantages may contribute to a better overall understanding of the emergence of pottery, especially among mobile groups. The fact that disposable utilitarian pottery seems to be relatively rare in recent contexts does not mean that it was absent in the distant past. Perhaps pottery came to have a greater perceived permanence only as it be- 
came a more embedded element of material cultural traditions, or perhaps traditions of disposable pottery persisted as populations shifted to more sedentary lifestyles but have yet to be fully recognised.

While disposable pottery may have been a component of early pottery production, it is difficult to say how important this component was. As noted above, it is difficult to quantify disposable pottery, as it may not readily survive, and at the same time, disposable pots that do survive may be difficult to differentiate from ones that were intended to have a long use-life. While I have argued that disposable pots, at least those with more utilitarian roles, may be characterised as expediently-produced vessels exhibiting a low investment of time and resources, this is not to say that all expediently produced vessels should be considered disposable. Some coarse, lowfired vessels may have been valued and kept for their properties as cooking vessels (Skibo, Schiffer 1995). But a longer use-life should be demonstrated rather than assumed. Evidence for a long use-life might include repair holes or evidence that pots were transported from their locus of production. In such cases, disposable pottery may not have been a significant part of the ceramic repertoire, or people may have produced it alongside vessels that were intended to be more durable. Given the inherent flexibility of pottery as a craft, it should perhaps be unsurprising that a single group of people should approach it in multiple ways. It is also worth pointing out that disposable pots, like 'ugly' pottery in general (Skibo, Schiffer 1995.83), should not be considered irrelevant to broader social or economic proces- ses. Carl Knappett (2011.143), for example, demonstrates how the simple, standardised, and probably disposable Minoan conical cup could have played an important role in carrying Cretan Palatial consumption practices across social networks in the southern Aegean.

This paper deals with how disposable pottery could fit into the technological traditions of mobile groups. Further work is needed to describe the diversity of early pottery assemblages and to explain why pottery developed in certain contexts, both among settled groups and more mobile ones. It might be revealed that disposable pottery was a minor and relatively unimportant element in a rather complex process; it may also turn out, however, that the apparent permanence of pottery derives partly from the fact that fired clay vessels, and more often parts of vessels, can survive for very long periods. In some cases, this permanence of pottery may not have been intended by the people who made and used it.

Thanks to Peter Jordan and Lisa Maher for making valuable comments on an earlier draft of this paper and thanks to Gareth Perry for references on craggans. Some of the ideas in this paper were included in a presentation given to the Ceramics Interest Group at the Archaeology Centre, University of Toronto. Thanks to Jill Hilditch and Stan Klassen for inviting me to give that presentation and thanks to members of the Group for comments and ideas.

\section{References}

Arnold D. 1985. Ceramic Theory and Cultural Process. Cambridge University Press. Cambridge.

Barnett W. K. and Hoopes J. W. (eds.) 1995. The Emergence of Pottery: Technology and Innovation in Ancient Societies. Smithsonian Institution Press. Washington.

Beck M. E. 2009. Residential Mobility and Ceramic Exchange: Ethnography and Archaeological Implications. Journal of Archaeological Method and Theory 16: 320356.

Bernbeck R. 2008. An Archaeology of Multisited Communities. In H. Barnard and W. Wendrich (eds.), The Archa- eology of Mobility: Old World and New World Nomadism. Cotsen Institute of Archaeology, University of California, Los Angeles: 43-77.

Betts A. V. G. (ed.) 1998. The Harra and the Hamad: Excavations at Surveys in Eastern Jordan, Volume 1. Sheffield Academic Press. Sheffield.

2008. Things to do with Sheep and Goats: Neolithic Hunter-Forager-Herders in North Arabia. In H. Barnard and W. Wendrich (eds.), The Archaeology of Mobility: Old World and New World Nomadism. Cotsen Institute of Archaeology, University of California, Los Angeles: $25-42$. 
Birmingham J. 1975. Traditional Potters of Kathmandu Valley: an Ethnoarchaeological Study. Man 10: 370-386.

Boaretto E., Wu X. H., Yuan J. R., Bar-Yosef O., Chu V., Pan Y., Liu K. X., Cohen D., Jiao T. L., Li S. C., Gu H. B., Goldberg P. and Weiner S. 2009. Radiocarbon Dating of Charcoal and Bone Collagen Associated with Early Pottery at Yuchanyan Cave, Hunan Province, China. Proceedings of the National Academy of Sciences of the United States of America 106: 9595-9600.

Brown J. A. 1989. The Beginnings of Pottery as an Economic Process. In S. E. Van Der Leeuw and R. Torrence (eds.), What's New? A Closer Look at the Process of Innovation. Unwin Hyman, London: 203-224.

Chazan M. and Lehner M. 1990. An Ancient Analogy: Pot Baked Bread in Ancient Egypt and Mesopotamia. Paléorient 16: 21-35.

Close A. E. 1995. Few and Far Between: Early Ceramics in North Africa. In W. K. Barnett and J. W. Hoopes (eds.), The Emergence of Pottery: Technology and Innovation in Ancient Societies. Smithsonian Institution Press, Washington: $23-37$.

Crombé P. 2009. Early Pottery in Hunter-Gatherer Societies of Western Europe. In P. Jordan and M. Zvelebil (eds.), Ceramics Before Farming: the Dispersal of Pottery among Prehistoric Eurasian Hunter-Gatherers. University College London Institute of Archaeology, Left Coast Press, Walnut Creek: 477-498.

Driver H. E. and Massey W. C. 1957. Comparative Studies of North American Indians. Transactions of the American Philosophical Society 47: 165-456.

Eerkens J. W. 2003. Residential Mobility and Pottery Use in the Western Great Basin. Current Anthropology 44: $728-738$.

2008. Nomadic Potters: Relationships between Ceramic Technologies and Mobility Strategies. In H. Barnard and W. Wendrich (eds.), The Archaeology of Mobility: Old World and New World Nomadism. Cotsen Institute of Archaeology, University of California, Los Angeles: 307-326.

Gebauer A. B. 1995. Pottery Production and the Introduction of Agriculture in Southern Scandinavia. In W. K. Barnett and J. W. Hoopes (eds.), The Emergence of Pottery: Technology and Innovation in Ancient Societies. Smithsonian Institution Press, Washington: 99-112.

Gheorghiu D. (ed.) 2009. Early Farmers, Late Foragers, and Ceramic Traditions: On the Beginning of Pottery in the Near East and Europe. Cambridge Scholars Publishing. Newcastle upon Tyne.

Goulder J. 2010. Administrators' Bread: An Experimentbased Re-assessment of the Functional and Cultural Role of the Uruk Bevel-rim Bowl. Antiquity 84: 351-362.

Habu J. 2004. Ancient Jomon of Japan. Cambridge University Press. Cambridge.

Harry K. and Frink L. 2009. The Arctic Cooking Pot: Why Was It Adopted? American Anthropologist 111: 330343.

Hayden B. 1995. The Emergence of Prestige Technologies and Pottery. In W. K. Barnett and J. W. Hoopes (eds.), The Emergence of Pottery: Technology and Innovation in Ancient Societies. Smithsonian Institution Press, Washington: $257-265$.

1998. Practical and Prestige Technologies: the Evolution of Material Systems. Journal of Archaeological Method and Theory 5: 1-55.

2009. Foreword. In P. Jordan and M. Zvelebil (eds.), Ceramics Before Farming: the Dispersal of Pottery among Prehistoric Eurasian Hunter-Gatherers. University College London Institute of Archaeology, Left Coast Press, Walnut Creek: 19-26.

Hoopes J. W. and Barnett W. K. 1995. The Shape of Early Pottery Studies. In W. K. Barnett and J. W. Hoopes (eds.), The Emergence of Pottery: Technology and Innovation in Ancient Societies. Smithsonian Institution Press, Washington: 1-7.

Jordan P. and Zvelebil M. (eds.) 2009a. Ceramics Before Farming: the Dispersal of Pottery among Prehistoric Eurasian Hunter-Gatherers. University College London Institute of Archaeology, Left Coast Press, Walnut Creek.

2009b. Ex Oriente Lux: the Prehistory of Hunter-Gatherer Ceramic Dispersals. In P. Jordan and M. Zvelebil (eds.), Ceramics Before Farming: the Dispersal of Pottery among Prehistoric Eurasian Hunter-Gatherers. University College London Institute of Archaeology, Left Coast Press, Walnut Creek: 33-89.

Kadowaki S., Gibbs K., Allentuck A. and Banning E. B. 2008. Late Neolithic Settlement in Wadi Ziqlab, Jordan: al-Basatîn. Paléorient 34: 105-129.

Kaner S. 2009. Long-term Innovation: the Appearance and Spread of Pottery in the Japanese Archipelago. In P. Jordan and M. Zvelebil (eds.) Ceramics Before Farming: the Dispersal of Pottery among Prehistoric Eurasian 
Hunter-Gatherers. University College London Institute of Archaeology, Left Coast Press, Walnut Creek: 93-119.

Keally C. T., Taniguchi Y. and Kuzmin Y. V. 2003. Understanding the Beginnings of Pottery Technology in Japan and Neighboring East Asia. The Review of Archaeology 24: 3-14.

Knappett C. 2011. An Archaeology of Interaction: Network Perspectives on Material Culture and Society. Oxford University Press. Oxford.

Köhler-Rollefson I. 1992. A Model for the Development of Nomadic Pastoralism on the Transjordanian Plateau. In 0. Bar-Yosef and A. Khazanov (eds.), Pastoralism in the Levant: Archaeological Materials in Anthropological Perspectives. Prehistory Press, Madison: 11-18.

Kuzmin Y. V. 2006. Chronology of the Earliest Pottery in East Asia: Progress and Pitfalls. Antiquity 80: 362-371.

Lu T. L.-D. 2010. Early Pottery in China. Asian Perspectives 49: 1-42.

Millard A. R. 1988. The Bevelled-rim Bowls: their Purpose and Significance. Iraq 50: 49-58.

Mitchell A. 1880. The Past in the Present: What is Civilisation? David Douglas. Edinburgh.

Ochsenschlager E. 1974. Mud Objects from al-Hiba: a Study in Ancient and Modern Technology. Archaeology 27: 162174.

Oyuela-Caycedo A. 1995. Rocks Versus Clay: the Evolution of Pottery Technology in the case of San Jacinto 1, Colombia. In W. K. Barnett and J. W. Hoopes (eds.), The Emergence of Pottery: Technology and Innovation in Ancient Societies. Smithsonian Institution Press, Washington: 133-144.

Pearson R. J. 2006. Jomon Hot Spot: Increasing Sedentism in South-western Japan in the Incipient Jōmon (14,000-9250 cal. BC) and Earliest Jomon (9250-5300 cal. BC) Periods. World Archaeology 38: 239-258.

Rice P. 1999. On the Origins of Pottery. Journal of Archaeological Method and Theory 6: 1-54.
Rollefson G. 0. and Köhler-Rollefson I. 1993. PPNC Adaptations in the First Half of the $6^{\text {th }}$ Millennium B.C. Paléorient 19: 33-42.

Rupp D. and Tsipopoulou M. 1999. Conical Cup Concentrations at Neopalatial Petras: a Case for a Ritualised Reception Ceremony with Token Hospitality. In P. P. Betancourt, V. Karageorghis, R. Laffineur and W.-D. Niemeier (eds.), Meletamata: Studies in Aegean Archaeology Presented to Malcolm H. Wiener as He Enters His 65th Year. Université de Liège, Liège: 729-739.

Simms S. R., Bright J. R. and Ugan A. 1997. Plain-ware Ceramics and Residential Mobility: a Case Study from the Great Basin. Journal of Archaeological Science 24: 779792.

Skibo J. M. and Schiffer M. B. 1995. The Clay Cooking Pot: an Exploration of Women's Technology. In J. M. Skibo, W. H. Walker and A. E. Nielson (eds.), Expanding Archaeo$\log y$. University of Utah Press, Salt Lake City: 80-91.

Skibo J. M., Schiffer M. B. \& Reid K. C. 1989. Organic-tempered Pottery: an Experimental Study. American Antiquity 54: 122-146.

Smith M. L. 2008. Urban Empty Spaces: Contentious Places for Consensus-building. Archaeological Dialogues 15: 216-231.

Taniguchi Y. 2006. Dating and Function of the Oldest Pottery in Japan. Current Research in the Pleistocene 23: 33-35.

Turnbull C. M. 1965. Wayward Servants: the Two Worlds of the African Pygmies. Greenwood Press. Westport.

Vitelli K. D. 1999. "Looking Up" at Early Ceramics in Greece. In J. M. Skibo and G. M. Feinman (eds.), Pottery and People: A Dynamic Interaction. University of Utah Press, Salt Lake City: 184-198.

Yasuda Y. (ed.) 2002. The Origins of Pottery and Agriculture. Roli Books/Lustre Press. New Delhi.

Zhang C. 2002. The Discovery of Early Pottery in China. In M. Budja (ed.), 9th Neolithic Studies. Documenta Praehistorica 29: 29-35. 